\title{
Thioredoxin overexpression in mitochondria showed minimum effects on aging and age-related diseases in male C57BL/6 mice
}

Madeline G. Roman a, Lisa C. Flores ${ }^{a}$, Geneva M. Cunningham ${ }^{a}$, Christie Cheng, Sara Dube $^{a}$, Colton Allen ${ }^{\mathrm{a}}$, Holly Van Remmen ${ }^{\mathrm{b}}$, Yidong Bai ${ }^{\mathrm{c}}$, Gene B. Hubbard ${ }^{\mathrm{a}, \mathrm{d}}$, Thomas L. Saunders ${ }^{\mathrm{e}}$, Yuji Ikeno $^{\mathrm{a}, \mathrm{d}, \mathrm{f}, *}$

\footnotetext{
${ }^{a}$ Barshop Institute for Longevity and Aging Studies, The University of Texas Health Science Center at San Antonio, San Antonio, TX,USA.

${ }^{b}$ Aging and Metabolism Research Program, Oklahoma Medical Research Foundation, Oklahoma City, OK, USA.

'Department of Cell Systems and Anatomy, The University of Texas Health Science Center at San Antonio, San Antonio, TX, USA.

${ }^{d}$ Department of Pathology, The University of Texas Health Science Center at San Antonio, San Antonio, TX,USA.

${ }^{e}$ Transgenic Animal Model Core, University of Michigan, Ann Arbor, MI ,USA.

${ }^{f}$ Geriatric Research Education and Clinical Center (GRECC), Audie L. Murphy VA Hospital, South Texas Veterans Health Care System, San Antonio, TX,USA.
}

\begin{abstract}
Background: In this study, the effects of overexpression of thioredoxin 2 (Trx2) on aging and age-related diseases were examined using Trx2 transgenic mice $\left[\operatorname{Tg}(\mathrm{TXN} 2)^{+/ 0}\right]$. Because our previous studies demonstrated that thioredoxin (Trx) overexpression in the cytosol (Trx1) did not extend maximum lifespan, this study was conducted to test if increased Trx2 expression in mitochondria shows beneficial effects on aging and age-related pathology.

Methods: Trx2 transgenic mice were generated using a fragment of the human genome containing the TXN2 gene. Effects of Trx2 overexpression on survival, age-related pathology, oxidative stress, and redox-sensitive signaling pathways were examined in male $\operatorname{Tg}(\mathrm{TXN} 2)^{+/ 0}$ mice.

Results: Trx2 levels were significantly higher (approximately 1.6- to 5-fold) in all of the tissues we examined in $\operatorname{Tg}(\mathrm{TXN} 2)^{+/ 0}$ mice compared to wild-type (WT) littermates, and the expression levels were maintained during aging (up to 22-24 months old). Trx2 overexpression did not alter the levels of Trx1, glutaredoxin, glutathione, or other major antioxidant enzymes. Overexpression of Trx2 was associated with reduced reactive oxygen species (ROS) production from mitochondria and lower isoprostane levels compared to WT mice. When we conducted the survival study, male $\operatorname{Tg}(\mathrm{TXN} 2)^{+/ 0}$ mice showed a slight extension (approximately 8-9\%) of mean, median, and 10th percentile lifespans; however, the survival curve was not significantly different from WT mice. Cross-sectional pathological analysis (22-24 months old) showed that $\operatorname{Tg}(\mathrm{TXN} 2)^{+/ 0}$ mice had a slightly higher severity of lymphoma; however, tumor burden, disease burden, and severity of glomerulonephritis and inflammation were similar to WT mice. Trx2 overexpression was also associated with higher c-Jun and c-Fos levels; however, mTOR activity and levels of NFKB p65 and p50 were similar to WT littermates.

Conclusions: Our findings suggest that the increased levels of Trx 2 in mitochondria over the lifespan in $\operatorname{Tg}(\mathrm{TXN} 2)^{+/ 0}$ mice showed a slight life-extending effect, reduced ROS production from mitochondria and oxidative damage to lipids, but showed no significant effects on aging and age-related diseases.
\end{abstract}

Keywords: Thioredoxin, transgenic Mouse, oxidative stress, aging

* Corresponding author: Yuji Ikeno

Mailing address: Barshop Institute for Longevity and Aging Studies, The University of Texas Health Science Center at San Antonio, 15355 Lambda Drive, San Antonio, TX 78245-3207, USA.

Email: ikeno@uthscsa.edu

Received: 26 February 2020 / Accepted: 17 March 2020

\section{Introduction}

Thioredoxin (Trx) has drawn much interest in biology, including aging, because of its unique ability to attenuate the level of oxidative stress/damage and alter redoxsensitive signaling, which could have diverse effects on 
pathophysiology. Trx is a small protein $(12 \mathrm{kDa})$ with two redox-active cysteine residues in the active center (CysGly-Pro-Cys) [1] and acts as the reductant for a variety of enzymes [1-7]. Trx also plays an important role in maintaining a reduced environment in cells through thioldisulfide exchange reactions [1]. This rapid and readily reversible reaction is ideal for protein function control via the redox state of structural or catalytic $\mathrm{SH}$ groups. In humans, Trx 1 and Trx 2 have been identified in different compartments of the cell, i.e., Trx1 in cytosol [8] and Trx2 in mitochondria [9].

To test the pathophysiological roles of Trx1 during aging, two transgenic mice overexpressing Trx 1 were generated using: 1) a transgene containing the human thioredoxin cDNA fused to the $\beta$-actin promoter $\left[\mathrm{Tg}(\operatorname{act}-\mathrm{TXN})^{+/ 0}\right.$ mice] [10] and 2) clones of the human TXN gene containing endogenous promoters $\left[\operatorname{Tg}(\mathrm{TXN})^{+/ 0}\right][11]$. The initial aging study demonstrated that $\operatorname{Tg}(\text { act-TXN })^{+/ 0}$ mice had an increased lifespan compared to their WT littermates $[10,12]$. However, the lifespan of WT C57BL/6 mice in their colony was shorter than WT C57BL/6 mice in aging colonies under optimal conditions, which indicates that the study was conducted under unconventional housing conditions. Therefore, an aging study with the same line of $\operatorname{Tg}(\text { act-TXN })^{+/ 0}$ mice under optimal housing conditions was conducted by our laboratory to examine the effects of increased levels of Trx 1 on aging and age-related diseases. Under optimal housing conditions, male and female $\mathrm{Tg}(\text { act-TXN })^{+/ 0}$ mice showed an extension of lifespan only in the earlier part of their lifespan; however, no increase in maximum lifespan was observed [13]. Because Tg(act$\mathrm{TXN})^{+/ 0}$ mice showed that the levels of overexpression significantly decreased with age possibly due to the $\beta$-actin promoter, we subsequently generated new transgenic mice with clones of the human TXN gene containing endogenous promoters $\left[\mathrm{Tg}(\mathrm{TXN})^{+/ 0}\right]$ to ensure that the transgene would be overexpressed throughout the lifespan [11]. The aging study with $\operatorname{Tg}(\mathrm{TXN})^{+/ 0}$ mice demonstrated that continuous overexpression of Trx 1 over the lifespan slightly extended the earlier part of life, but had no significant effects on median or maximum lifespans. $\operatorname{Tg}(\mathrm{TXN})^{+/ 0}$ mice also showed that Trx 1 overexpression accelerates cancer development in old mice [11], which is similar to the pathology results in $\operatorname{Tg}(\operatorname{act}-\mathrm{TXN})^{+/ 0}$ mice [13]. The results from two lines of Trx 1 transgenic mice showed that overexpression of Trx 1 in cytosol does not have beneficial effects in aged mice, i.e., no life-extending effects with enhanced tumor development in the later part of life.

These results led us to question whether increased levels of Trx 2 in mitochondria could play more important roles in aging, i.e., extend both the earlier and later part of lifespan and attenuate the development of age-related diseases. The study with mCAT mice [14] clearly demonstrated the importance of antioxidant overexpression in mitochondria in aging. In their study, overexpressing catalase in mitochondria significantly increased lifespan and reduced some types of cancers, while overexpressing catalase in other compartments of the cells (nucleus or peroxisome) did not change lifespan [14].

Thus, the purpose of this study is to examine the effects of Trx 2 overexpression in the mitochondria on aging. We conducted a survival study using transgenic mice generated with a clone of the human TXN2 gene containing an endogenous promoter $\left[\mathrm{Tg}(\mathrm{TXN} 2)^{+/ 0}\right]$. Here, we report that increased levels of Trx in mitochondria $\left[\mathrm{Tg}(\mathrm{TXN} 2)^{+/ 0}\right.$ mice] showed no significant changes in lifespan compared to WT mice, although a slight extension (approximately $8-9 \%$ ) of mean, median, and 10th percentile lifespans (not statistically significant) was observed. $\operatorname{Tg}(\mathrm{TXN} 2)^{+/ 0}$ mice also showed no significant effects on age-related pathological changes. Therefore, our results suggest that the overexpression of Trx 2 has minimal effects on aging and development of age-related diseases in male C57BL/6 mice.

\section{Materials and methods}

\section{Animals and animal husbandry}

We generated the $\operatorname{Tg}(\mathrm{TXN} 2)^{+/ 0}$ mice using the human thioredoxin 2 gene [a PAC clone (RP5-1119A7), Children's Hospital Oakland Research Institute's (CHORI) BACPAC Resources Center (BPRC), Oakland, CA], which contained the TXN2 gene and $13.7 \mathrm{~kb}$ and $6.6 \mathrm{~kb}$ of the 5'- and 3'-flanking sequences, respectively (Figure 1). These transgenic mice were produced by pronuclear microinjection of zygotes obtained from the mating of (C57BL/6J X SJL/J)F1 females with (C57BL/6J X SJL/ J)F1 males (Jackson Laboratory, stock no. 100012) and were backcrossed to C57BL/6 mice ten times. Male hemizygous transgenic mice $\left[\mathrm{Tg}(\mathrm{TXN} 2)^{+/ 0}\right]$ were crossed with $\mathrm{C} 57 \mathrm{BL} / 6$ females to generate hemizygous transgenic and WT control mice. All mice were fed a commercial chow (Teklad Diet LM485: Madison, WI) and acidified $(\mathrm{pH}=2.6-2.7)$ filtered reverse osmosis water ad libitum. To measure the amount of food consumption, the amount of chow removed from the cage hopper and the spillage (the chow on the bottom of the cage) were weighed monthly. Actual food consumed was calculated by subtracting the spillage from the chow removed from the hopper. All of the mice were weighed monthly. The mice were maintained pathogen-free in microisolator units on Tek FRESH ultra laboratory bedding. Sentinel mice housed in the same room and exposed weekly to bedding collected from the cages of experimental mice were sacrificed on receipt and every six months thereafter for monitoring of viral antibodies (Mouse Level II Complete Antibody Profile CARB, Ectro, EDIM, GDVII, LCM, M. Ad-FL, M. Ad-K87, MCMV, MHV, M. pul., MPV, MVM, Polyoma, PVM, Reo, Sendai; BioReliance, Rockville, MD). All tests were negative.

We chose young (4-6 months old) and old (22-24 months old) age groups for the experiments described below because: 1) C57BL/6 mice reach their optimum reproductivity at 3-7 months of age and 2) have increased incidence 

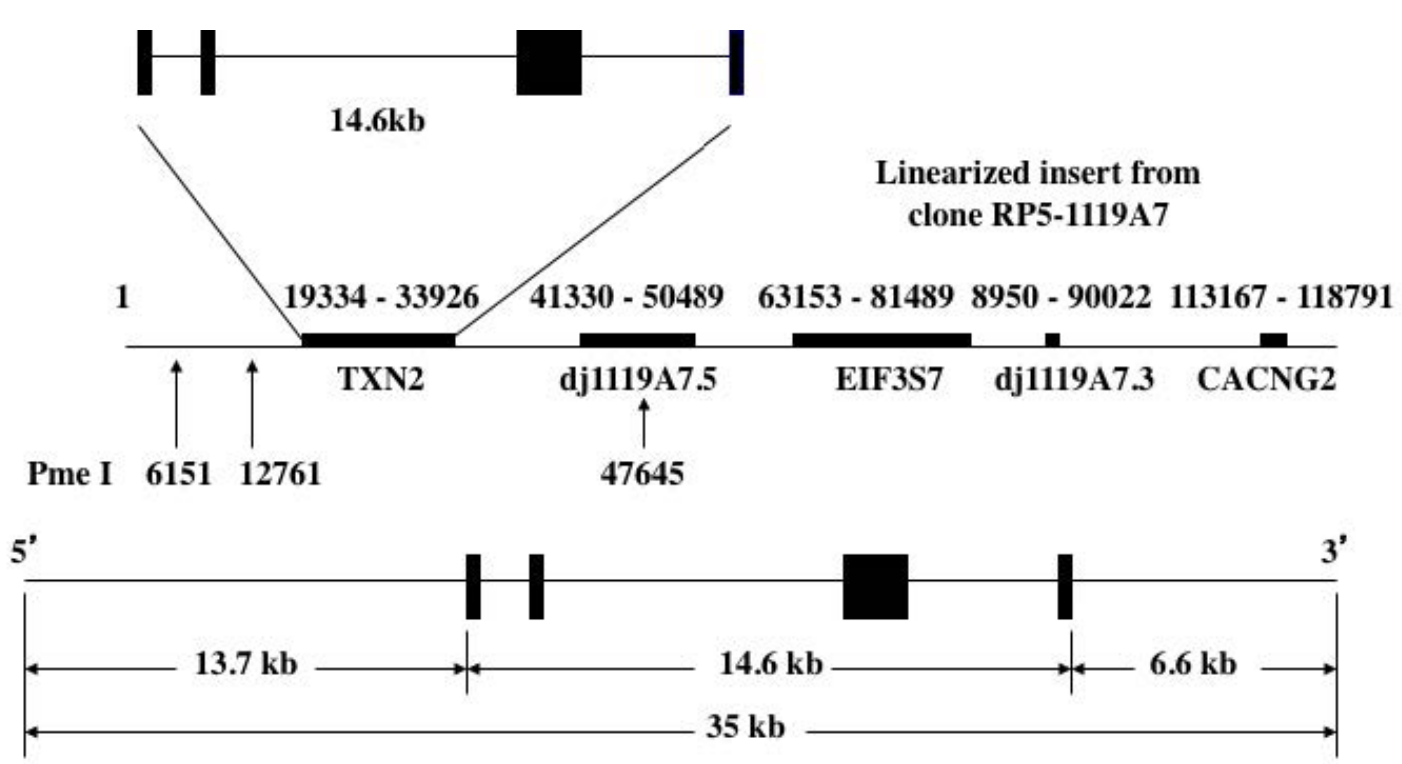

Figure 1. DNA construct for $\mathbf{T g}(\mathbf{T X N} 2)^{+/ 0}$ mice. The human thioredoxin 2 gene (TXN2) with $13.7 \mathrm{~kb}$ and $6.6 \mathrm{~kb}$ of the 5 '- and 3 '-flanking sequences was used to generate $\operatorname{Tg}(\mathrm{TXN} 2)^{+10}$ mice by pronuclear microinjection of zygotes from the mating of $(\mathrm{C} 57 \mathrm{BL} / 6 \mathrm{~J} \mathrm{X} \mathrm{SJL} / \mathrm{J}) \mathrm{F} 1 \mathrm{females}$ with $(\mathrm{C} 57 \mathrm{BL} / 6 \mathrm{~J}$ $\mathrm{X} \mathrm{SJL} / \mathrm{J}) \mathrm{F} 1$ males.

of cancers after 20 months of age followed by advanced stages of cancer around 26-30 months of age. For some of the assays, only liver was used because there is a large amount of information available with respect to agerelated changes, and liver is one of the major sites for the development of spontaneous tumors in C57BL/6 mice.

\section{Determination of $\operatorname{Trx} 2$ expression}

Thioredoxin 2 ( $\operatorname{Tr} x 2$ ) levels were measured using the mitochondrial fraction obtained from several tissues (liver, kidney, heart, brain, lung, spleen, and testes) from young (4-6 months old) and liver from old (22-24 months old) $\mathrm{Tg}(\mathrm{TXN} 2)^{+/ 0}$ and WT mice as previously described $[13,15]$. Western blot analysis was performed using rabbit anti-Trx2 polyclonal antibody (Catalog No. LF-PA0012; LabFrontier, Seoul, South Korea). After incubation with the primary antibodies, membranes were incubated with the respective peroxidase-linked secondary antibodies (Catalog No. P0217; Dako, Carpinteria, CA). Chemiluminescence was detected using the ECL Western blot detection kit (Amersham Biosciences Corp., Piscataway, NJ).

\section{Trx1 levels}

Cytosolic fractions obtained from tissues homogenized as previously described [13] were used to determine Trx1 levels in liver obtained from young (4-6 months old) $\operatorname{Tg}(\mathrm{TXN} 2)^{+/ 0}$ and WT mice by Western blot analysis using goat anti-human Trx1 polyclonal antibodies (Catalog No. 705; American Diagnostica, Inc., Greenwich, CT). These antibodies recognize total Trx1 (both oxidized and reduced forms). After incubation with the primary antibody, membranes were incubated with the peroxidase-linked secondary antibody (Catalog No. P0449; Dako, Carpinteria, CA). Chemiluminescence was detected with an ECL
Western blot detection kit (Amersham Biosciences Corp., Piscataway, NJ).

\section{Glutaredoxin and total glutathione levels}

Glutaredoxin (Grx) levels were measured using total homogenate fractions obtained from the liver of young (4-6 months old) $\operatorname{Tg}(\mathrm{TXN} 2)^{+/ 0}$ and WT mice as previously described [13]. Western blot analysis was performed using goat anti-human glutaredoxin polyclonal antibody (Cata$\log$ No. 710; American Diagnostica, Inc., Greenwich, CT). After incubation with the primary antibodies, membranes were incubated with the respective peroxidase-linked secondary antibodies (Catalog No. P0449; Dako, Carpinteria, CA). Chemiluminescence was detected using the ECL Western blot detection kit (Amersham Biosciences Corp., Piscataway, NJ). The levels of total glutathione were determined using the Bioxytech GSH-420 kit (Catalog No. 21023; Oxis International, Inc., Foster City, CA) in several tissues (liver, kidney, heart, brain, lung, spleen, and testes) from young (4-6 months old) $\operatorname{Tg}(\mathrm{TXN} 2)^{+/ 0}$ and WT mice.

Determination of major antioxidant enzyme activities: $\mathrm{Cu} / \mathrm{ZnSOD}$, MnSOD, glutathione peroxidase, and catalase

The activities of major antioxidant enzymes $(\mathrm{Cu} / \mathrm{ZnSOD}$, MnSOD, glutathione peroxidase (GPx), and catalase) were measured in tissue homogenates obtained from the liver of young (4-6 months old) $\mathrm{Tg}(\mathrm{TXN} 2)^{+/ 0}$ and WT mice. The supernatants were used for the antioxidant defense enzymatic activity assay. GPx activity in tissue homogenates was measured by the assay described by Sun et al. [16]. Catalase activity was determined by measuring the decomposition of hydrogen peroxide at $520 \mathrm{~nm}$ using 


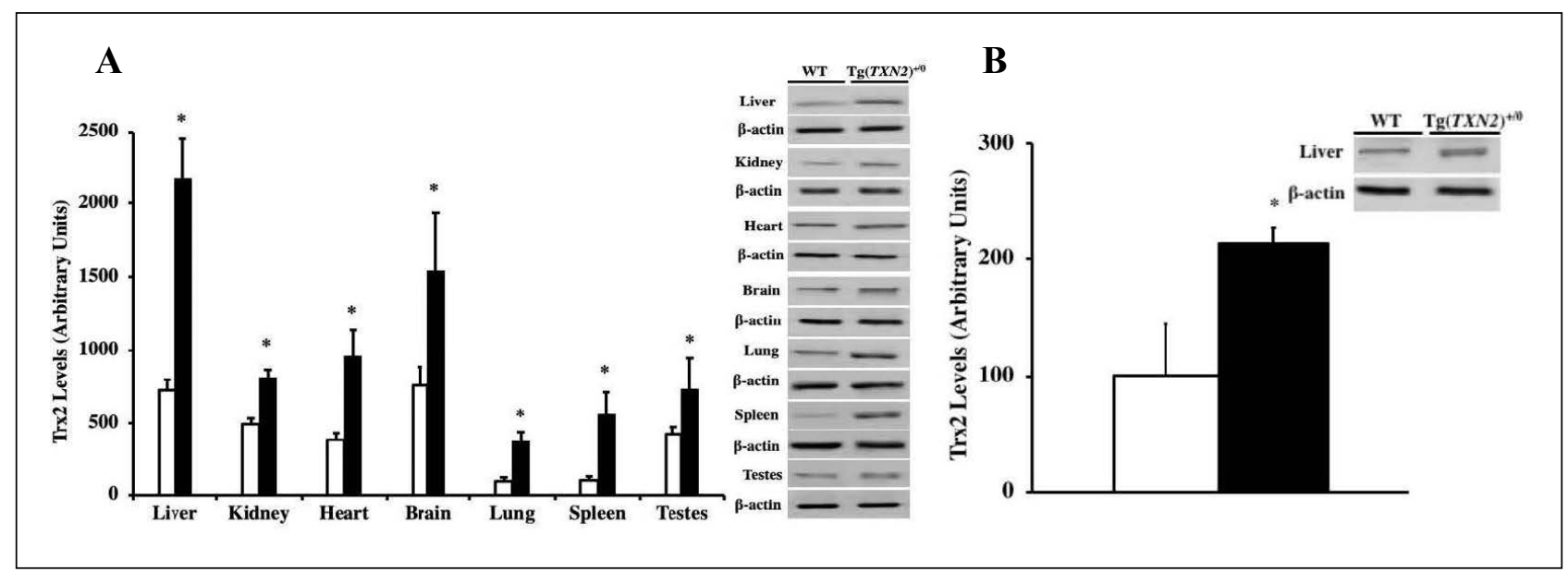

Figure 2. Overexpression of Trx 2 in young and old Tg(TXN2) $)^{+/ 0}$ mice and their WT littermates. The levels of Trx 2 protein were determined by Western blot in various tissues of 4-6 months old (Figure 2A: left) and in the liver of 22-24 months old (Figure 2B: right) Tg(TXN2) ${ }^{+/ 0}$ (closed bar) and WT (open bar) mice. Trx2 levels were significantly higher in both young and old $\operatorname{Tg}(\mathrm{TXN} 2)^{+/ 0}$ mice compared to their WT littermates $(* P<0.05)$. The data are the mean SEM from three to five mice.

the Catalase-520TM assay kit (OxisResearchTM, Portland, OR). MnSOD and $\mathrm{Cu} / \mathrm{ZnSOD}$ levels were measured by activity gels as previously described $[17,18]$. Images of the gels were analyzed by ImageQuant software.

\section{Reactive oxygen species (ROS) production from mito- chondria}

$\mathrm{H} 2 \mathrm{O} 2$ release from isolated mitochondria obtained from skeletal muscle was measured using the fluorogenic probe, Amplex Red (Molecular Probes, Eugene, OR) as previously described [19].

\section{Assays for lipid peroxidation (F2-isoprostane levels)}

The levels of F2-isoprostanes were determined using gas chromatography/mass spectrometry as described by Morrow and Roberts [20]. The plasma samples obtained from young (4-6 months old) $\operatorname{Tg}(\mathrm{TXN} 2)^{+/ 0}$ and WT mice were added to HPLC ( $\mathrm{pH} 3.0)$ water and mixed by vortex. After centrifugation $\left(2,500 \times \mathrm{g}\right.$ for 3 minutes at $\left.4^{\circ} \mathrm{C}\right)$, the $\mathrm{F} 2$ isoprostanes were extracted from the clear supernatants with a C18 Sep-Pak column and a silica Sep-Pak column. The F2-isoprostanes were then converted to pentafluorobenzyl esters and subjected to thin layer chromatography. The F2-isoprostanes were further converted to trimethylsilyl ether derivatives, and the F2-isoprostane levels were quantified by gas chromatography/mass spectrometry. An internal standard, 8-isoPGF2a-d4 (Cayman Chemical, Ann Arbor, MI), was added to the samples at the beginning of extraction to correct the yield of the extraction process. The amounts of F2-isoprostanes were expressed as picograms of 8-Iso-prostaglandin F2 per milliliter of plasma sample.

\section{Assays for DNA oxidation (8-oxodG levels)}

The levels of oxidative damage to DNA were measured by the amount of 8-oxo-2-deoxyguanosine (oxo8dG) in DNA as described by Hamilton et al. [21]. DNA was isolated from liver obtained from young (4-6 months old)
$\operatorname{Tg}\left(\mathrm{TXN}_{2}\right)^{+/ 0}$ and WT mice by $\mathrm{NaI}$ extraction using the DNA Extractor WB Kit (Wako Chemicals USA, Inc., Richmond, VA). The data are expressed as the ratio of nmoles of oxo8dG to 105 nmoles of $2 \mathrm{dG}$.

\section{Survival study}

Mice in the survival groups were allowed to live out their lives, and the lifespan for individual mice was determined by recording the age of spontaneous death. A survival study consisting of $19 \mathrm{Tg}(\mathrm{TXN} 2)^{+/ 0}$ and $22 \mathrm{WT}$ male mice was conducted. The survival curves were compared statistically using the log-rank test [22]. The mean, median, and 10 th percentile (when $90 \%$ of the mice had died) survival were calculated for each group. The mean survivals for each experimental group were compared to the respective WT group by performing a Student's t-test upon log-transformed survival times. The median and 10th percentile survivals for each group were compared to the WT group using a score test adapted from Wang et al. [23].

\section{Cross-sectional pathological assessment}

The cross-sectional pathological analyses were conducted with $23 \mathrm{Tg}(\mathrm{TXN} 2)^{+/ 0}$ mice and $19 \mathrm{WT}$ male mice. After the gross pathological examinations, the following organs and tissues were excised and preserved in $10 \%$ buffered formalin: brain, pituitary gland, heart, lung, trachea, thymus, aorta, esophagus, stomach, small intestine, colon, liver, pancreas, spleen, kidneys, urinary bladder, reproductive system (prostate, testes, epididymis, and seminal vesicles), thyroid gland, adrenal glands, parathyroid glands, psoas muscle, knee joint, sternum, and vertebrae. Any other tissues with gross lesions were also excised. The fixed tissues were processed conventionally, embedded in paraffin, sectioned at $5 \mathrm{~m}$, and stained with hematoxylineosin. The diagnosis of each histopathological change was made with histological classifications in aging mice as previously described [24,25]. A list of pathological lesions was constructed for each mouse that included both 


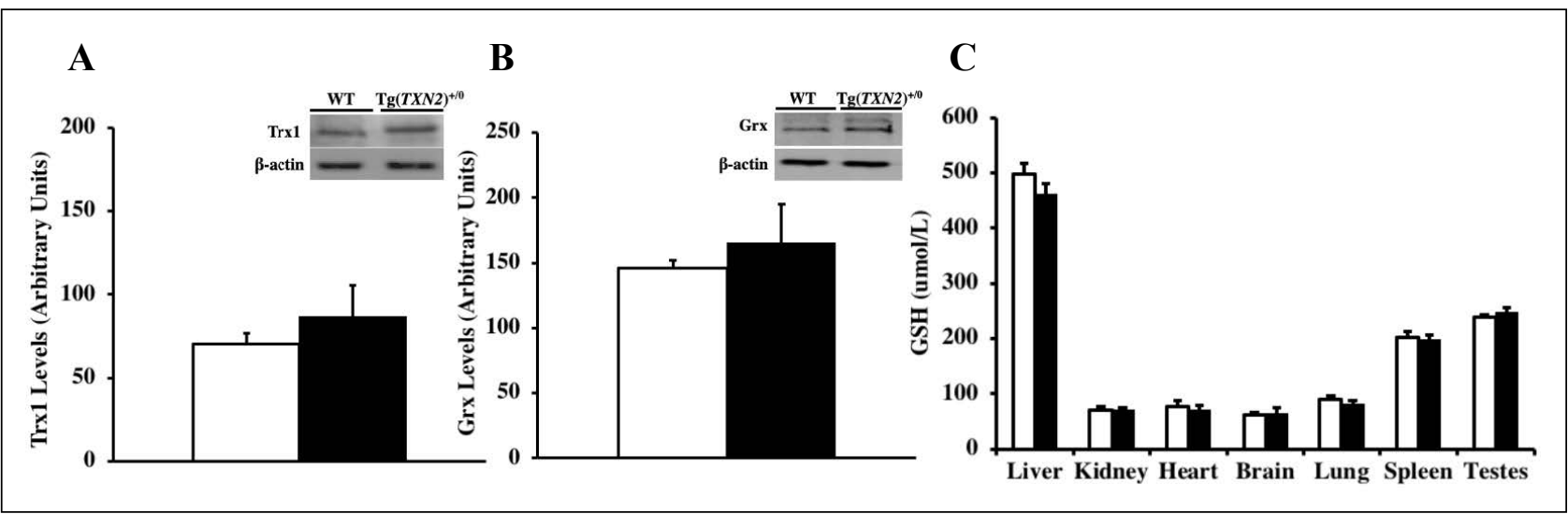

Figure 3. Levels of Trx1, glutaredoxin, and total glutathione in Tg(TXN2) ${ }^{+/ 0}$ and WT mice. The levels of Trx1 (Figure 3A: left), glutaredoxin (Figure 3B: center), and total glutathione (Figure 3C: right) were measured in the liver of 4-6 months old Tg(TXN2) $(\mathrm{closed}$ bar) and WT mice (open bar). No significant difference was observed in Trx1, glutaredoxin, or total glutathione in $\operatorname{Tg}(\mathrm{TXN} 2)^{+/ 0} \mathrm{mice}$ compared to WT mice. The data in figures $3 a-3 c$ are the mean SEM from three to five mice.

neoplastic and non-neoplastic diseases. Based on these histopathological data, the tumor burden, disease burden, and severity of each lesion in each mouse were assessed as previously described [25-27].

\section{Determination of c-Jun and c-Fos levels}

Total cell lysates from liver of young (4-6 months old) $\operatorname{Tg}\left(\mathrm{TXN}_{2}\right)^{+/ 0}$ and WT mice were prepared, and detection of c-Jun (Catalog No. 9165; Cell Signaling Technology, Inc., Danvers, MA) and c-Fos (Catalog No. 4384; Cell Signaling Technology, Inc., Danvers, MA) were performed using Western blots. The amount of c-Jun and cFos was quantified by a densitometer, and the data were expressed as the relative amount of protein in lysates using $\beta$-actin as an internal standard.

\section{Determination of $\mathrm{mTOR}$ signaling pathway activity and HIF-1a levels}

Levels of p70S6K1 and 4E-BP1 (phosphorylated and nonphosphorylated forms) were measured in the total cell lysates from liver of young (4-6 months old) $\operatorname{Tg}(\mathrm{TXN} 2)^{+/ 0}$ and WT mice by Western blot analysis using mouse p70S6K1, phospho-p70S6K1, 4E-BP1, and phospho-4EBP1 antibodies (Cell Signaling Technology, Inc., Danvers, MA).

Total cell lysates from liver of young (4-6 months old) $\operatorname{Tg}(\mathrm{TXN} 2)^{+/ 0}$ and WT mice were prepared, and detection of p70S6K1 and 4E-BP1 (phosphorylated and non-phosphorylated forms) was performed using Western blots. The amount of p70S6K1 and 4E-BP1 (phosphorylated and non-phosphorylated forms) was quantified by a densitometer, and the data were expressed as the relative amount of protein in lysates using $\beta$-actin as an internal standard.

Total cell lysates from liver of young (4-6 months old) $\operatorname{Tg}(\mathrm{TXN} 2)^{+/ 0}$ and WT mice were prepared, and detection of HIF-1 $\alpha$ (Catalog No. Ab82832; Abcam, Cambridge, MA) was performed using Western blots. The amount of HIF- $1 \alpha$ was quantified by a densitometer, and the data were expressed as the relative amount of protein in lysates using $\beta$-actin as an internal standard.

\section{Measurement of the NFкB pathway}

The levels of NFkB (p65 and p50) were measured in the total cell lysates from liver of young (4-6 months old) $\operatorname{Tg}(\mathrm{TXN} 2)^{+/ 0}$ and WT mice by Western blot analysis using mouse NFкB p65 (Catalog No. 3034; Cell Signaling Technology, Inc., Danvers, MA) and p50 (Catalog No. 3035; Cell Signaling Technology, Inc., Danvers, MA) antibodies.

\section{Statistical analysis}

Unless otherwise specified, all experiments were done at least in triplicate. Data were expressed as means \pm SEM and were analyzed by the non-parametric test ANOVA. All pair-wise contrasts were computed using Tukey error protection at $95 \% \mathrm{CI}$, unless otherwise indicated. Differences were considered statistically significant at $P<0.05$.

\section{Results}

\section{Overexpression of $\operatorname{Trx} 2$ in tissues from $\operatorname{Tg}(\mathrm{TXN} 2)^{+/ 0}$ mice}

The levels of Trx 2 in tissues (liver, kidney, heart, brain, lung, spleen, and testes) from young (4-6 months old) $\operatorname{Tg}(\mathrm{TXN} 2)^{+/ 0}$ and WT mice were measured using Western blot analysis. The Trx 2 protein levels were significantly higher (approximately 1.6- to 5-fold) in all of the seven tissues examined in young $\operatorname{Tg}(\mathrm{TXN} 2)^{+/ 0}$ mice compared to their WT littermates (Figure 2A; $P<0.05$ ). The levels of Trx 2 overexpression were maintained in the liver of old (22-24 months old) $\mathrm{Tg}(\mathrm{TXN} 2)^{+/ 0}$ mice (Figure $2 \mathrm{~B} ; P<$ $0.05)$.

Levels of Trx1, glutaredoxin, total glutathione, and major antioxidant enzymes in tissues from $\operatorname{Tg}(\mathrm{TXN} 2)^{+/ 0}$ mice

To examine whether the increased levels of Trx 2 altered the levels of Trx1, glutaredoxin, and glutathione, which have biological functions similar to $\operatorname{Tr} x 2$, we measured the levels of Trx1, glutaredoxin, and total glutathione in 
A

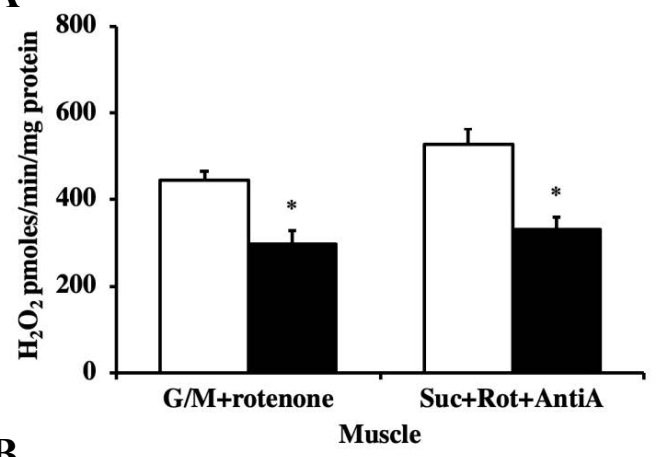

B

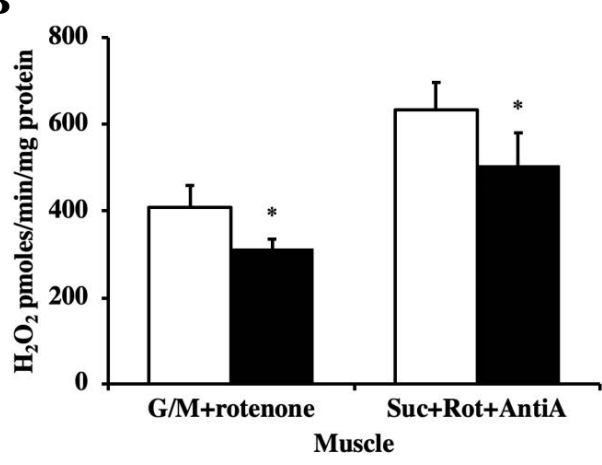

Figure 4. Hydrogen peroxide production in young and old Tg(TXN2) ${ }^{+/ 0}$ and WT mice. The Amplex Red assay was performed in the skeletal muscle of 4-6 months (Figure 4A: left) and 22-24 months old (Figure 4B: right) $\operatorname{Tg}(\mathrm{TXN} 2)^{+/ 0}$ (closed bar) and WT (open bar) mice. Under different experimental conditions, $\mathrm{H} 2 \mathrm{O} 2$ production was significantly less in mitochondria from both young and old $\operatorname{Tg}(\mathrm{TXN} 2)^{+/ 0}$ mice compared to WT mice $(* P<0.05)$. The values are the mean \pm SEM of five mice per group.

liver and other tissues obtained from young (4-6 months old) $\operatorname{Tg}(\mathrm{TXN} 2)^{+/ 0}$ and WT mice. The data in Figure 3 show that Trx1 (Figure 3A) and glutaredoxin (Figure 3B) levels in the liver were similar between $\operatorname{Tg}(\mathrm{TXN} 2)^{+/ 0}$ and WT mice at 4-6 months of age $(P>0.05)$. The levels of total glutathione in the tissues (liver, kidney, heart, brain, lung, spleen, and testes) were also similar between young (4-6 months old) $\mathrm{Tg}(\mathrm{TXN} 2)^{+/ 0}$ and WT mice (Figure $3 \mathrm{C}$; $P>0.05)$.

The activities of major antioxidant enzymes $(\mathrm{Cu} / \mathrm{ZnSOD}$, MnSOD, glutathione peroxidase (GPx), and catalase) were similar between young (4-6 months old) $\mathrm{Tg}(\mathrm{TXN} 2)^{+/ 0}$ and WT mice (data not shown).

\section{Hydrogen peroxide production from mitochondria}

$\mathrm{H}_{2} \mathrm{O}_{2}$ release from isolated mitochondria obtained from skeletal muscle was measured using the fluorogenic probe, Amplex Red (Molecular Probes, Eugene, OR) as previously described [19]. The $\mathrm{H}_{2} \mathrm{O}_{2}$ release from isolated mitochondria from skeletal muscle was significantly less in both young (4-6 months old) and old (22-24 months old) $\operatorname{Tg}(\mathrm{TXN} 2)^{+/ 0}$ mice compared to their WT littermates (Figures 4A and 4B; $P<0.05$ ).

Lipid peroxidation (F2-isoprostane levels) and DNA
A

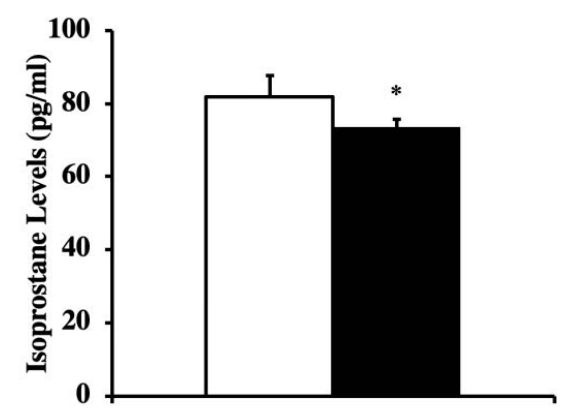

B

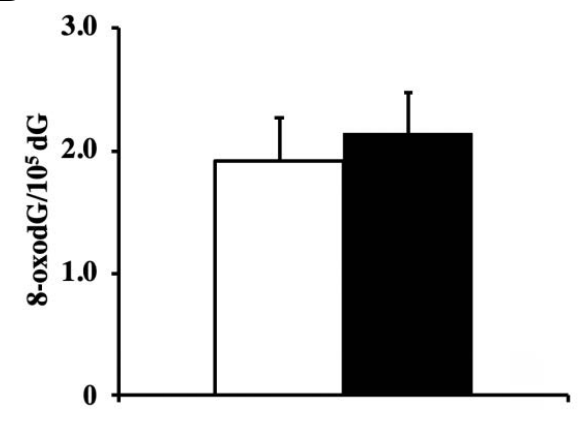

Figure 5. Levels of F2-isoprostanes and DNA oxidation in $\operatorname{Tg}(\mathrm{TXN} 2)^{+/ 0}$ and WT mice. F2-isoprostanes levels were measured in plasma samples from 4-6 months old (Figure 5A: left) and DNA oxidation (8-oxodG) in liver from 4-6 months old (Figure 5B: right) $\operatorname{Tg}(\mathrm{TXN} 2)^{+/ 0}$ (closed bar) and WT (open bar) mice. The F2-isoprostane levels were significantly lower in $\operatorname{Tg}(\mathrm{TXN} 2)^{+/ 0}$ mice than in WT control mice $(* P<0.05)$. Levels of DNA oxidation in the livers of $\operatorname{Tg}(\mathrm{TXN} 2)^{+/ 0}$ and WT mice showed no significant difference. The data are the mean SEM from five mice.

\section{oxidation (8-oxodG levels)}

We tested whether Trx 2 overexpression protects against oxidative damage by measuring levels of lipid peroxidation (F2 isoprostanes) in serum and DNA oxidation (8-oxodG) in liver from young (4-6 months old) $\mathrm{Tg}(\mathrm{TXN} 2)^{+/ 0}$ and WT mice. Levels of F2-isoprostanes were significantly lower in young (4-6 months old) $\mathrm{Tg}(\mathrm{TXN} 2)^{+/ 0}$ mice compared to WT mice (Figure 5A; $P$ $<0.05)$, however, $\operatorname{Tg}(\mathrm{TXN} 2)^{+/ 0}$ mice had only $13-14 \%$ lower levels of F2-isoprostanes compared to WT mice, in spite of the significant ROS production from mitochondria (Figures 4A and 4B). Although Trx2 overexpression reduced the ROS production from mitochondria and oxidative damage to lipids, levels of DNA oxidation measured by 8-oxodG were similar between young (4-6 months old) $\mathrm{Tg}(\mathrm{TXN} 2)^{+/ 0}$ and WT mice (Figure $5 \mathrm{~B} ; P>0.05$ ).

\section{Survival curves, body and organ weights}

The survival curves of $\operatorname{Tg}(\mathrm{TXN} 2)^{+/ 0}$ and WT mice are presented in Figure 6. The survival study was conducted with $19 \mathrm{Tg}(\mathrm{TXN} 2)^{+/ 0}$ and $22 \mathrm{WT}$ male mice. The survival curves were not significantly different between $\mathrm{Tg}(\mathrm{TXN} 2)^{+/ 0}$ and WT mice (Log-rank: $P>0.05$ ). The mean, median, and 10th percentile survival for WT mice 


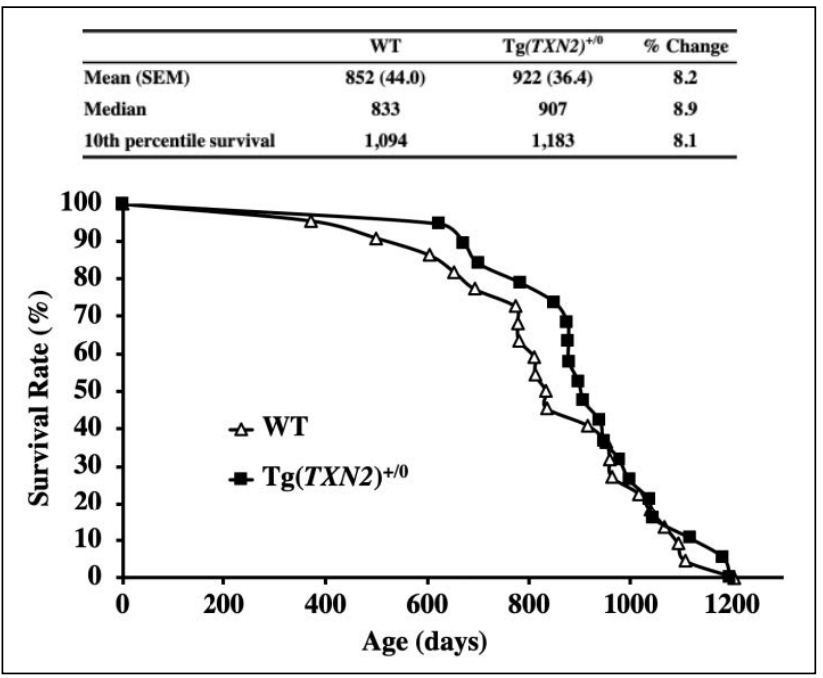

Figure 6. The survival curves of $\operatorname{Tg}(\mathrm{TXN2})^{+/ 0}$ and WT mice. The survival curves, mean, median, and 10th percentile lifespans (days), and percent differences of $\operatorname{Tg}(\mathrm{TXN} 2)^{+/ 0}$ (closed squares) and WT (open triangles) mice are presented. The cohort consists of $19 \operatorname{Tg}(\mathrm{TXN} 2)^{+/ 0}$ and 22 WT male mice. The survival curves did not show a significant difference between $\operatorname{Tg}(\mathrm{TXN} 2)^{+/ 0}$ and WT mice $(P>0.05) . \operatorname{Tg}(\mathrm{TXN} 2)^{+/ 0}$ mice had a slightly longer mean $(8.2 \%)$, median $(8.9 \%)$, and 10 th percentile $(8.1 \%)$ lifespans compared to WT mice, which were not statistically significant $(P>0.05)$.

were 852,833 , and 1,094 days, respectively (Figure $6)$. The mean, median, and 10th percentile survival for $\operatorname{Tg}(\mathrm{TXN} 2)^{+/ 0}$ mice were 922, 907, and 1,183 days, respectively (Figure 6). $\mathrm{Tg}(\mathrm{TXN} 2)^{+/ 0}$ mice had slightly longer mean $(8.2 \%)$, median $(8.9 \%)$, and 10 th percentile $(8.1 \%)$ lifespans compared to WT mice, however, these differences did not reach statistical significance $(P>0.05)$.

The body and organ weights were similar between $\operatorname{Tg}(\mathrm{TXN} 2)^{+/ 0}$ and WT mice (Table 1). Food consumption was also similar between $\operatorname{Tg}(\mathrm{TXN} 2)^{+/ 0}$ and WT mice (data not shown).

\section{Cross-sectional pathology}

The cross-sectional pathological analyses of 23 $\operatorname{Tg}(\mathrm{TXN})^{+/ 0}$ and $19 \mathrm{WT}$ mice $(22-24$ months old) showed that the major disease in these mice was neoplastic disease. The tumors observed were lymphoma, hemangioma/ hemangiosarcoma in the liver and spleen, pulmonary adenocarcinoma, hepatocellular carcinoma, and adenoma in the thyroid gland, and the most prevalent tumor was lymphoma, which is consistent with the pathology data from C57BL/6 mice and mice overexpressing Trx 1 [11,13].

First, we compared the number of different types of tumors (tumor burden) for each mouse in both $\operatorname{Tg}(\mathrm{TXN} 2)^{+/ 0}$ and WT groups because aging mice may have several different types of tumors. As the data in Figure 7A show, the tumor burden for the $\operatorname{Tg}(\mathrm{TXN} 2)^{+/ 0}$ mice is similar to WT mice $(P>0.05)$. The incidence of lymphoma was similar between $\operatorname{Tg}(\mathrm{TXN} 2)^{+/ 0}$ and WT mice (data not shown). $\operatorname{Tg}(\mathrm{TXN} 2)^{+/ 0}$ mice had a slightly higher severity of lymphoma than WT mice, which was not statistically signifi- cant (Figure 7B; $P>0.05$ ).

Next, we compared the severity of major non-neoplastic disease between the two groups. Severity of glomerulonephritis and inflammation, which were the most common non-neoplastic lesions observed in these mice, were com-

Table 1. Body and organ weights of $\operatorname{Tg}(\mathrm{TXN} 2)^{+/ 0}$ young mice.

\begin{tabular}{lcc}
\hline & WT $(n=6)$ & Tg(TXN2) $)^{+/ 0}(n=6)$ \\
\hline Body Weight $(\mathrm{g})$ & $30.711 \pm 1.222$ & $29.198 \pm 2.138$ \\
Liver $(\mathrm{g})$ & $1.847 \pm 0.146$ & $1.688 \pm 0.126$ \\
Spleen (g) & $0.100 \pm 0.007$ & $0.132 \pm 0.026$ \\
Pancreas (g) & $0.185 \pm 0.012$ & $0.185 \pm 0.024$ \\
Heart (g) & $0.177 \pm 0.006$ & $0.187 \pm 0.015$ \\
Lung (g) & $0.207 \pm 0.006$ & $0.197 \pm 0.010$ \\
Left Kidney (g) & $0.272 \pm 0.009$ & $0.256 \pm 0.031$ \\
Right Kidney (g) & $0.302 \pm 0.018$ & $0.301 \pm 0.020$ \\
Left Testis (g) & $0.115 \pm 0.004$ & $0.120 \pm 0.005$ \\
Right Testis (g) & $0.118 \pm 0.005$ & $0.126 \pm 0.005$ \\
Brain (g) & $0.408 \pm 0.012$ & $0.412 \pm 0.008$ \\
\hline
\end{tabular}

A

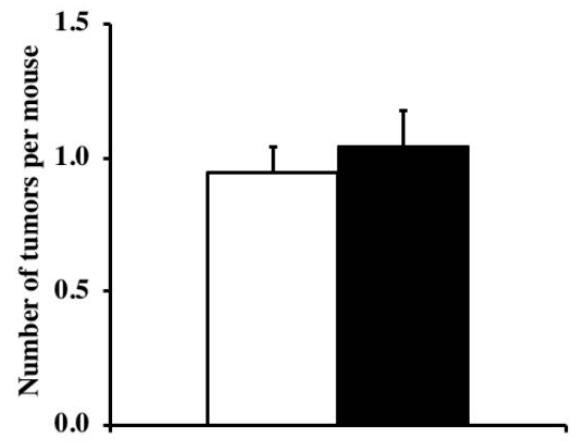

B

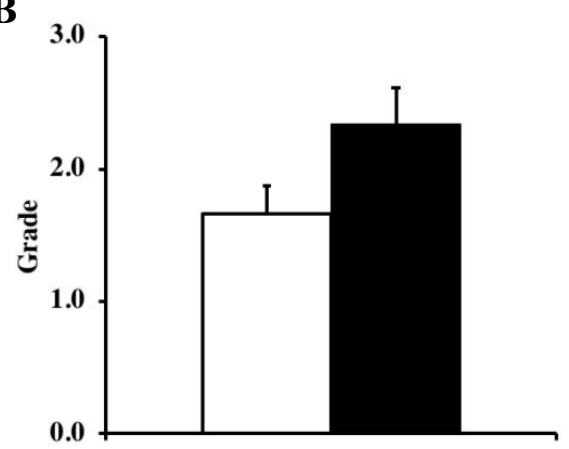

Figure 7. Tumor burden and severity of lymphoma in $\operatorname{Tg}(\mathrm{TXN} 2)^{+/ 0}$ and WT mice. The number of different types of tumors, tumor burden (Figure 7A: left) and the severity of lymphoma (Figure 7B: right) in $\operatorname{Tg}(\mathrm{TXN} 2)^{+/ 0}$ (closed bar) and WT (open bar) mice were compared at $22-$ 24 months old. The cohort consists of $23 \operatorname{Tg}(\mathrm{TXN} 2)^{+/ 0}$ and $19 \mathrm{WT}$ male mice. The tumor burden for the $\operatorname{Tg}(\mathrm{TXN} 2)^{+0}$ mice is similar to WT mice and the severity of lymphoma is slightly higher in $\operatorname{Tg}(\mathrm{TXN} 2)^{+/ 0}$ mice compared to their WT littermates, which were not statistically significant $(P>0.05)$. 


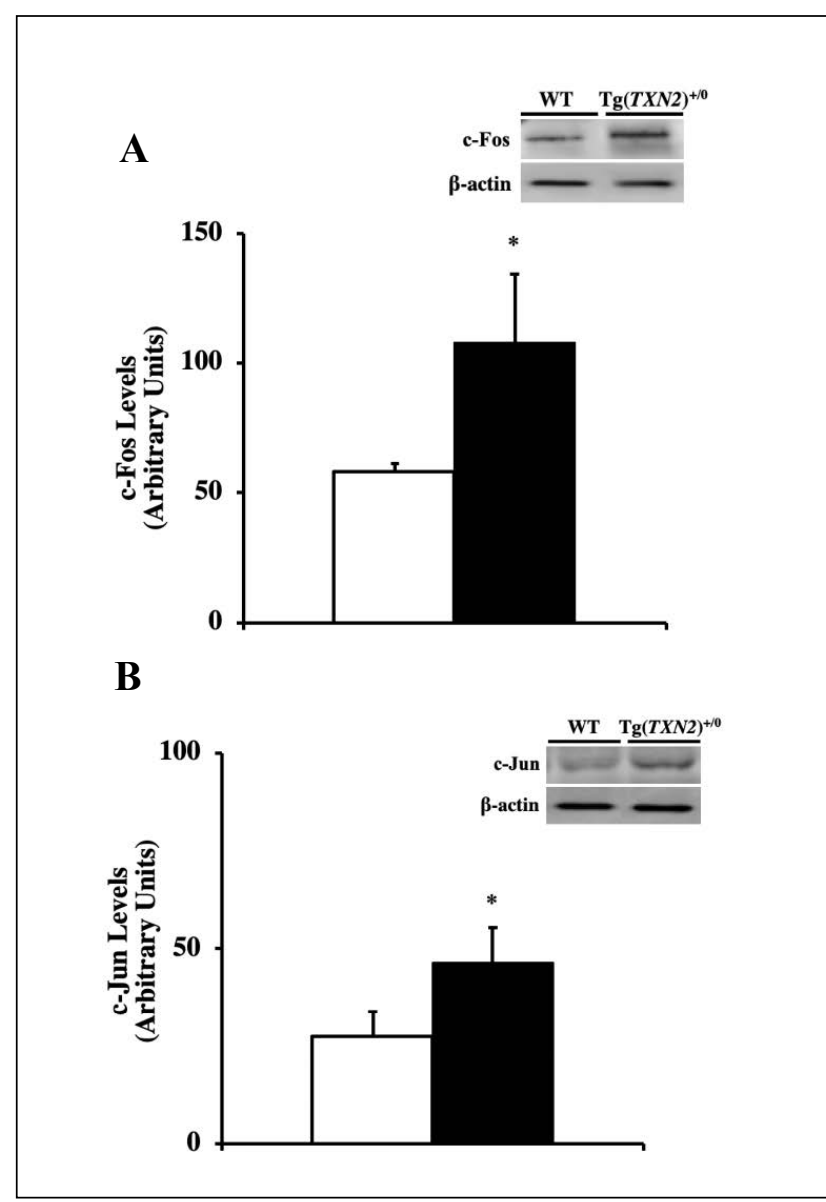

Figure 8. Levels of c-Fos and c-Jun in Tg(TXN2) ${ }^{+/ 0}$ and WT mice. The levels of c-Fos (Figure 8A: left) and c-Jun (Figure 8B: right) were measured in the liver of 4-6 months old $\mathrm{Tg}(\mathrm{TXN} 2)^{+/ 0}$ (closed bar) and WT mice (open bar) by Western blot. The c-Fos and c-Jun levels were significantly higher in $\operatorname{Tg}(\mathrm{TXN} 2)^{+/ 0}$ mice than in WT control mice $(* P<$ $0.05)$. The data are the mean SEM from three to five mice.

pared between $\operatorname{Tg}(\mathrm{TXN} 2)^{+/ 0}$ and WT mice. No significant changes were found regarding the severity of glomerulonephritis or inflammation in $\operatorname{Tg}(\mathrm{TXN} 2)^{+/ 0}$ and WT mice (data not shown). The disease burden, defined as the total number of histopathological changes in a body, which can also serve as a good index of age-related accumulation of tissue and cell injury [24,26,27], were similar between $\operatorname{Tg}(\mathrm{TXN} 2)^{+/ 0}$ and WT mice (data not shown).

\section{Measurement of the c-Fos and c-Jun levels}

Since c-Fos and c-Jun are redox-sensitive transcription factors, and their levels are correlated to cancer development, the levels of c-Fos and c-Jun were measured using Western blot. The data in Figure 8 show that $\operatorname{Tg}(\mathrm{TXN} 2)^{+/ 0}$ mice had significantly higher levels of c-Fos and c-Jun compared to their WT littermates (Figures $8 \mathrm{a}$ and $8 \mathrm{~b}$, respectively; $P<0.05)$.

\section{Determination of mTOR signaling pathway activity and HIF-1a levels}

Since substantial evidence showed that mTOR activity is one of the key pathways for cancer development and

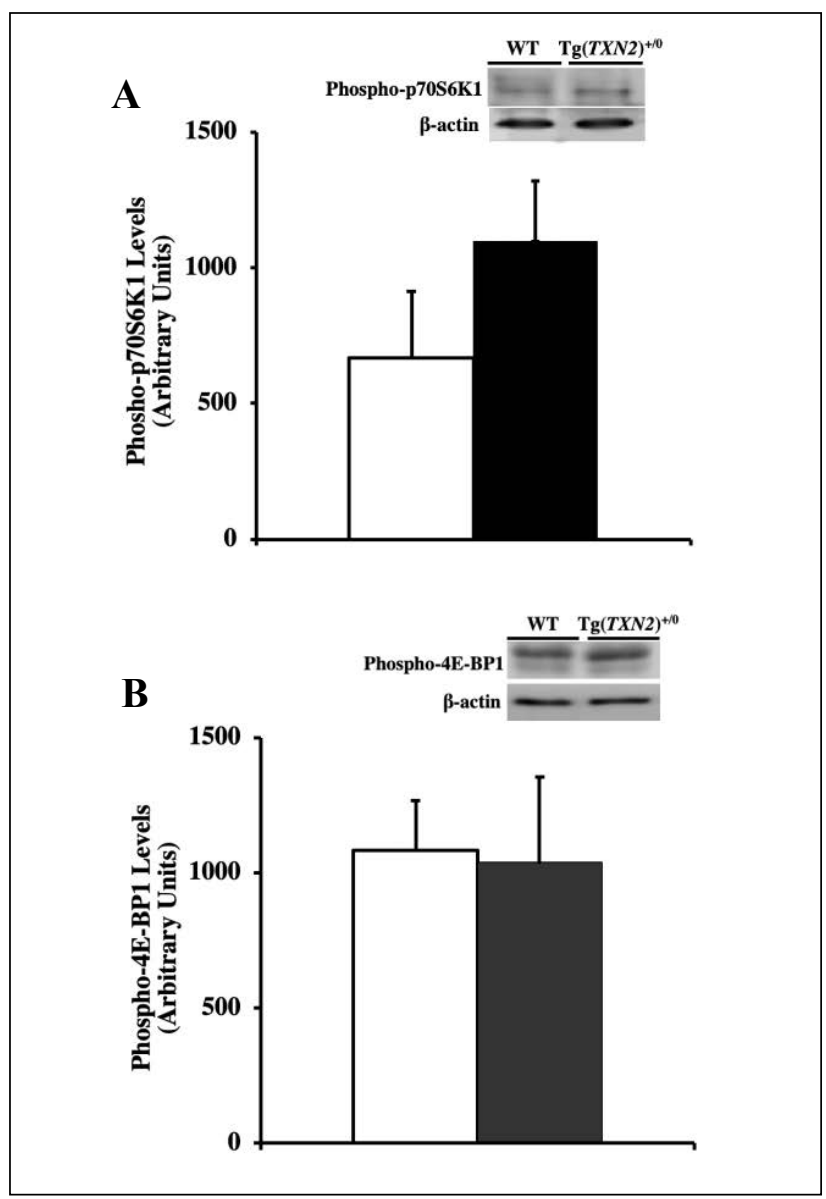

Figure 9. Levels of $m$ TOR in Tg(TXN2) $)^{+/ 0}$ and WT mice. The levels of phospho-p70S6K1 (Figure 9A: left) and phospho-4E-BP1 (Figure 9B: right) were measured in the liver of young (4-6 months old) $\operatorname{Tg}(\mathrm{TXN} 2)^{+/ 0}$ (closed bar) and WT (open bar) mice by Western blot analysis. The levels of phospho-p70S6K1 and phospho-4E-BP1 were similar between $\operatorname{Tg}(\mathrm{TXN} 2)^{+/ 0}$ and WT mice $(P>0.05)$. The data are the mean SEM from three to five mice.

lifespan, levels of p70S6K1 and 4E-BP1 (phosphorylated and non-phosphorylated forms) were measured in the total cell lysates from liver of $\operatorname{Tg}(\mathrm{TXN} 2)^{+/ 0}$ and WT mice by Western blot analysis using mouse p70S6K1, phosphop70S6K1, 4E-BP1, and phospho-4E-BP1 antibodies. The data in Figure 9A show that $\operatorname{Tg}(\mathrm{TXN} 2)^{+/ 0}$ mice had slightly higher levels of phospho-p70S6K1 compared to WT littermates, although the difference was not statistically significant (Figure 9A; $P>0.05$ ). Levels of phospho-4EBP1 were similar between $\operatorname{Tg}(\mathrm{TXN} 2)^{+/ 0}$ and WT mice (Figure 9B; $P>0.05$ ). In addition, the levels of HIF-1 $\alpha$, which also plays important roles in cancer development, were similar between $\operatorname{Tg}(\mathrm{TXN} 2)^{+/ 0}$ and WT littermates (data not shown).

\section{Measurement of the NFאB pathway}

Since NFKB is one of the redox-sensitive transcription factors, which plays important roles in oxidative stress, inflammation, apoptosis, and cancer, the levels of $\mathrm{NF} \kappa \mathrm{B}$ (p65 and p50) were measured using Western blot. The data in Figure 10 show that $\operatorname{Tg}(\mathrm{TXN} 2)^{+/ 0}$ mice had similar 

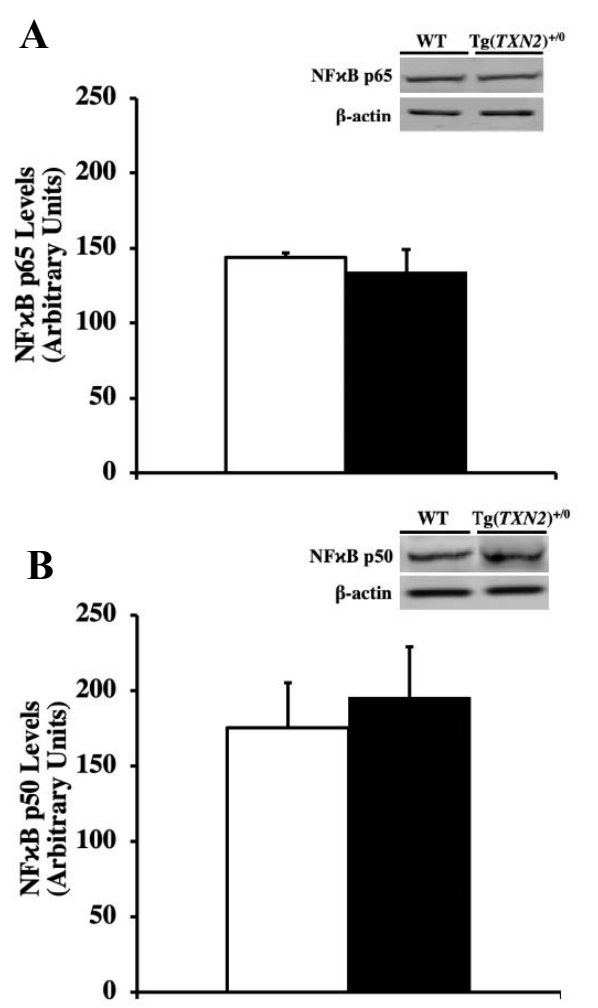

Figure 10. Levels of NFKB p65 and NFKB p50 in $\operatorname{Tg}(\mathrm{TXN} 2)^{+/ 0}$ and WT mice. The levels of NFKB p65 (Figure 10A: left) and NFkB p50 (Figure 10B: right) were measured in the liver of young (4-6 months old) $\operatorname{Tg}(\mathrm{TXN} 2)^{+/ 0}$ (closed bar) and WT (open bar) mice. The levels of NFKB p65 and NFKB p50 were similar between $\operatorname{Tg}(\mathrm{TXN} 2)^{+/ 0}$ and WT mice $(P>0.05)$. The data are the mean SEM from three to five mice.

levels of NF $\kappa \mathrm{B}$ p 65 and $\mathrm{NF} \kappa \mathrm{B}$ p50 compared to their WT littermates (Figures 10A and 10B, respectively; $P>0.05$ ).

\section{Discussion}

After the initial discovery as the major reductant for a variety of enzymes in the early 1960s, unique biological roles of thioredoxin ( $\operatorname{Trx}$ ) have been well documented [1]. Trx plays important roles as a hydrogen donor to enzymes involved in reductive reactions [e.g., ribonucleotide reductase, which reduces ribonucleotides to deoxyribonucleotides for DNA synthesis; peroxiredoxin (Prx), which reduces peroxides [4-6] and methionine sulfoxide (MetO) reductase, which reduces $\mathrm{MetO}$ in proteins and provides protection against oxidative stress [2,3,7]. Trx also plays important roles to protect cells and tissues from oxidative stress by maintaining a reduced environment in cells through thiol-disulfide exchange reactions [10,2830]. Trx has two forms in human cells: one in cytosolic (hTrx1) [8] and another in mitochondrial (hTrx2) [9]. Essential roles of Trx 1 and Trx 2 in mammals were further proven by the studies with knockout mice null for either Trx 1 or Trx2, which are embryonically lethal [31,32]. Although the important roles of Trx along with thioredoxin interacting protein (Txnip) in pathophysiology have been well documented [1,33], the exact roles of Trx on aging and age-related pathology in mammals had been largely unknown.

To test the role of Trx in aging, a lifespan study was first conducted using the mice overexpressing Trx 1 generated with a transgene containing the human thioredoxin cDNA fused to the $\beta$-actin promoter $\left[\mathrm{Tg}(\operatorname{act}-\mathrm{TXN})^{+/ 0}\right.$ mice] $[10,12]$. The study demonstrated that Trx1 overexpression resulted in an increased lifespan compared to their WT littermates $[10,12]$. However, there were shortcomings in the study; the survival study was conducted under conventional housing conditions and the lifespan of WT C57BL/6 mice in their colony was shorter than WT $\mathrm{C} 57 \mathrm{BL} / 6$ mice in aging colonies under optimal conditions. Thus, our laboratory conducted an aging study to examine the effects of increased levels of Trx 1 on oxidative stress and aging under optimal housing conditions [13], using $\operatorname{Tg}(\text { act-TXN })^{+/ 0}$ mice. Our study demonstrated that Trx 1 overexpression showed a significant increase in the survival of male $\operatorname{Tg}($ act- $\mathrm{TXN}){ }^{+/ 0}$ mice compared to WT mice only during the first half of their lifespan, but no increase of lifespan was observed in later part of life. $\operatorname{Tg}(\text { act-TXN })^{+/ 0}$ mice showed that the levels of overexpression significantly decreased with age possibly due to the $\beta$-actin promoter driving expression of the transgene [13]. Subsequently, we generated new transgenic mice with clones of the human TXN gene containing endogenous promoters $\left[\mathrm{Tg}(\mathrm{TXN})^{+/ 0}\right]$ to test the effects of continuous Trx 1 overexpression over the lifespan on aging and agerelated diseases [11]. $\operatorname{Tg}(\mathrm{TXN})^{+/ 0}$ mice showed some beneficial effects in the earlier part of life but had no significant effects on median or maximum lifespans, which was accompanied with accelerated cancer development in old mice [11]. These results are consistent with the observations in $\operatorname{Tg}(\text { act-TXN })^{+/ 0}$ mice.

The results from two lines of Trx1 transgenic mice clearly demonstrated that overexpression of Trx 1 in cytosol has beneficial effects only in the earlier part of life. These results also led us to question whether increased expression of Trx 2 in the mitochondria plays more important roles in aging because the importance of antioxidant overexpression in mitochondria in aging and age-related disease was strongly suggested by a study using mice overexpressing catalase in mitochondria [14]. In their study, overexpressing catalase in the mitochondria significantly extended lifespan and attenuated age-related diseases compared to their WT littermates, while overexpressing catalase in the nucleus or peroxisome did not have beneficial effects on aging [14]. Thus, the purpose of this study was to test the effects of Trx 2 overexpression in the mitochondria on aging and age-related diseases using male $\operatorname{Tg}(\mathrm{TXN} 2)^{+/ 0}$ C57BL/6 mice.

To directly test the effects of Trx 2 overexpression on aging and age-related diseases, we generated the $\operatorname{Tg}(\mathrm{TXN} 2)^{+/ 0}$ mice using the human thioredoxin 2 gene. Young (4-6 months old) male $\mathrm{Tg}(\mathrm{TXN} 2)^{+/ 0}$ mice showed that levels of Trx 2 were significantly higher in all the tis- 
sues examined compared to WT control mice. The levels of Trx 2 were 1.6- to 5-fold higher in all of the tissues examined. The increased levels of $\operatorname{Trx} 2$ in male $\operatorname{Tg}(\mathrm{TXN} 2)^{+/ 0}$ mice did not alter Trx1, glutaredoxin or total glutathione levels. The activities of major antioxidant enzymes $(\mathrm{Cu} /$ ZnSOD, MnSOD, glutathione peroxidase (GPx), and catalase) were also similar between young (4-6 months old) $\operatorname{Tg}(\mathrm{TXN} 2)^{+/ 0}$ and WT mice. The Trx 2 overexpression suppressed the hydrogen peroxide production from isolated skeletal muscle mitochondria from both young (4-6 months old) and old (22-24 months old) $\operatorname{Tg}(\mathrm{TXN} 2)^{+/ 0}$ mice compared to WT control mice as expected.

Although the skeletal muscle mitochondria obtained from $\operatorname{Tg}(\mathrm{TXN} 2)^{+/ 0}$ mice showed less hydrogen peroxide production compared to WT control mice, the effects of Trx2 overexpression on oxidative damage were minimal. Plasma isoprostane levels were approximately $13-14 \%$ less in $\operatorname{Tg}(\mathrm{TXN} 2)^{+/ 0}$ compared to WT control mice, however, the levels of DNA oxidation measured by 8-oxodG were similar between $\operatorname{Tg}(\mathrm{TXN} 2)^{+/ 0}$ and WT control mice.

Our survival study showed that the survival curve of male $\operatorname{Tg}(\mathrm{TXN} 2)^{+/ 0}$ mice was not significantly different from WT control mice. Although the mean, median, and 10th percentile lifespans of male $\operatorname{Tg}(\mathrm{TXN} 2)^{+/ 0}$ mice were approximately $8-9 \%$ longer than WT control mice, these differences were not statistically significant. The cross-sectional pathology showed that the total number of tumors (tumor burden) was similar between $\operatorname{Tg}(\mathrm{TXN} 2)^{+/ 0}(1.04)$ and WT control mice (0.95). The incidence of lymphoma, a major neoplastic disease, was also similar between $\operatorname{Tg}(\mathrm{TXN} 2)^{+/ 0}$ and WT control mice. The severity of lymphoma was slightly higher in $\operatorname{Tg}(\mathrm{TXN} 2)^{+/ 0}$ mice compared to WT mice, although the difference was not statistically significant. These pathological observations indicate that overexpression of $\operatorname{Trx} 2$ in mitochondria may play a similar role in the development and growth of lymphoma as the overexpression of Trx1 [11,13], i.e., accelerate the growth and development of lymphoma as they age.

Subsequently, we measured several signaling pathways (i.e., mTOR, NFאB, and c-Jun/Fos) because substantial evidence shows that these pathways play important roles in cancer development and lifespan and can also be attenuated by Trx. Although overexpression of Trx 2 in mitochondria suppressed the ROS production from mitochondria and reduced levels of lipid peroxidation, its effects on signaling pathways were minimal. Our data showed the levels of phospho-p70S6K1, phospho-4E-BP1, NFкB p65, and NFKB p50 were similar between $\operatorname{Tg}(\mathrm{TXN} 2)^{+/ 0}$ and WT littermates, which suggests that the mTOR and NFאB pathways were not changed by the overexpression of Trx 2 in mitochondria. On the other hand, we saw increased levels of c-Jun and c-Fos in $\operatorname{Tg}(\mathrm{TXN} 2)^{+/ 0}$ mice compared to their WT littermates. Activator protein 1 (AP-1), is a complex of proteins of the Jun and Fos families. In mammals, three Jun proteins (c-Jun, Jun B, and Jun D) and four Fos family proteins (c-Fos, Fos B, Fra-1, and Fra-2) have been identified. AP-1 proteins bind to TPA-response elements (TRE) or AP-1 binding sites to transcriptionally activate effector genes, which have been shown to stimulate cell proliferation and transformation. AP-1 DNA binding activity has been shown to be enhanced by Trx via Ref-1 by the reduction of a single conserved cysteine residue in the DNA binding domain of each subunit [34]. Therefore, increased levels of c-Fos and c-Jun may contribute to slightly accelerated cancer development in $\operatorname{Tg}(\mathrm{TXN} 2)^{+/ 0}$ mice.

Although the minimal effects of Trx 2 overexpression on aging and age-related pathology are somewhat disappointing, the outcome of this study along with our previous works with the mice overexpressing Trx 1 could indicate overexpression of Trx in either cytosol or mitochondria alone may have limited biological effects. In other words, synergetic effects of Trx 1 and Trx 2 may be required to have more robust effects on pathophysiology during aging. This notion is supported by our recent study that overexpression of Trx in both the cytosol and mitochondria in TXNTg x TXN2Tg mice unexpectedly had a shorter lifespan and enhanced tumor development compared to WT mice [35]. To further test the synergetic effects of Trx overexpression in the cytosol and mitochondria on aging and age-related disease, our laboratory is currently testing if the down-regulation of Trx in both the cytosol and mitochondria could have anti-aging and/or anti-cancer effects.

\section{Declarations}

Acknowledgements: We acknowledge the Pathology Core in the San Antonio Nathan Shock Center (P30AG013319) for pathological analyses.

This research was supported by the VA Merit Review grant from the Department of Veteran Affairs (Y.I.), NIH grant AG13319 (Y.I.), The American Federation for Aging Research (AFAR) grant (Y.I.), and a grant from the Glenn Foundation (Y.I.).

Conflict of interest: Yuji Ikeno is a member of the Editorial Board of Aging Pathobiology and Therapeutics.All authors declare no conflict of interest and were not involved in the journal's review or desicions related to this manuscript.

\section{References}

1. Arnér ESJ, Holmgren A. Physiological functions of thioredoxin and thioredoxin reductase. Eur J Biochem. 2000;267(20):6102-6109.

2. Brot N, Weissbach L, Werth J, Weissbach H. Enzymatic reduction of protein-bound methionine sulfoxide. Proc Natl Acad Sci USA. 1981;78(4):2155-2158.

3. Brot $\mathrm{N}$, Weissbach $\mathrm{H}$. Peptide methionine sulfoxide reductase: biochemistry and physiological role. Biopolymers. 2000;55(4):288-296.

4. Chae HZ, Kang SW, Rhee SG. Isoforms of mammalian peroxiredoxin that reduce peroxides in presence of thioredoxin. Methods Enzymol. 1999a;300:219-226.

5. Chae HZ, Kim HJ, Kang SW, Rhee SG. Characterization of 
three isoforms of mammalian peroxiredoxin that reduce peroxides in the presence of thioredoxin. Diabetes Res Clin Pract. 1999b;45(2-3):101-112.

6. Kim K, Kim IH, Lee KY, Rhee SG, Stadtman ER. The isolation and purification of a specific "protector" protein which inhibits enzyme inactivation by a thiol/Fe(III)/ 02 mixed-function oxidation system. J Biol Chem. 1988;263(10):4704-4711.

7. Levine RL, Berlett BS, Moskovitz J, Mosoni L, Stadtman ER. Methionine residues may protect proteins from critical oxidative damage. Mech Ageing Dev. 1999;107(3):323-332.

8. Tagaya Y, Maeda Y, Mitsui A, Kondo N, Matsui H, Hamuro J, Brown N, Arai K-I, Yokota T, Wakasugi H, Yodoi J. ATLderived factor (ADF), an IL-2 receptor/Tac inducer homologous to thioredoxin; possible involvement of dithiol-reduction in the IL-2 receptor induction. EMBO J. 1989;8(3):757-764.

9. Spyrou G, Enmark E, Miranda-Vizuete A, Gustafsson J-A. Cloning and expression of a novel mammalian thioredoxin. J Biol Chem. 1997;272:2936-2941.

10. Takagi Y, Mitsui A, Nishiyama A, Nozaki K, Sono H, Gon Y, Hashimoto N, Yodoi J. Overexpression of thioredoxin in transgenic mice attenuates focal ischemic brain damage. Proc Natl Acad Sci USA. 1999;96(7):4131-4136.

11. Flores LC, Roman MG, Cunningham GM, Cheng C, Dube S, Allen C, Van Remmen H, Hubbard GB, Saunders TL, Ikeno Y. Continuous overexpression of thioredoxin 1 enhances cancer development and does not extend maximum lifespan in male C57BL/6 mice. Pathobiol Aging Age Relat Dis. 2018;8(1):1533754.

12. Mitsui A, Hamuro J, Nakamura H, Kondo N, Hirabayashi Y, Ishizaki-Koizumi S, Hirakawa T, Inoue T, Yodoi J. Overexpression of human thioredoxin in transgenic mice controls oxidative stress and life span. Antioxid Redox Signal. 2002;4(4):693-696.

13. Pérez VI, Cortez LA, Lew CM, Rodriguez M, Webb CR, Van Remmen H, Chaudhuri A, Qi W, Lee S, Bokov A, Fok W, Jones D, Richardson A, Yodoi J, Tominaga K, Hubbard GB, Ikeno Y. Thioredoxin 1 overexpression extends mainly the earlier part of life span in mice. J Gerontol. 2011;66(12):1286-1299.

14. Schriner SE, Linford NJ, Martin GM, Treuting P, Ogburn CE, Emond M, Coskun PE, Ladiges W, Wolf N, Van Remmen H, Wallace DC, Rabinovitch PS. Extension of murine life span by overexpression of catalase targeted to mitochondria. Science. 2005;308:1909-1911.

15. Pérez VI, Lew CM, Cortez LA, Webb CR, Rodriguez M, Liu Y, Qi W, Li Y, Chaudhuri A, Van Remmen H, Richardson A, Ikeno Y. Thioredoxin 2 haploinsufficiency in mice results in impaired mitochondrial function and increased oxidative stress. Free Radic Biol Med. 2008;44(5):882-892.

16. Sun Y, Elwell JH, Oberley LW. A simultaneous visualization of the antioxidant enzymes glutathione peroxidase and catalase on polyacrylamide gels. Free Radic Res Commun. 1988;5(2):67-75.

17. Beauchamp C, Fridovich I. Superoxide dismutase: improved assays and an assay applicable to acrylamide gels. Analyt Biochem. 1971;44(1):276-287.

18. Williams MD, Van Remmen H, Conrad CC, Huang TT, Epstein CJ, Richardson A. Increased oxidative damage is correlated to altered mitochondrial function in heterozygous manganese superoxide dismutase knockout mice. J Biol Chem. 1998;273(43):28510-28515.

19. Muller FL, Song W, Liu Y, Chaudhuri A, Pieke-Dahl S, Strong R, Huang TT, Epstein CJ, Roberts LJ, Csete M, Faulkner JA, and Van Remmen H. Absence of CuZn superoxide dismutase leads to elevated oxidative stress and acceleration of age-dependent skeletal muscle atrophy. Free Rad Biol Med. 2006;40(11):1993-2004.

20. Morrow JD, Roberts II LJ. The isoprostanes: current knowledge and directions for future research. Biochem Pharm. 1996;51(1):1-9.

21. Hamilton ML, Guo Z, Fuller CD, Van Remmen H, Ward WF, Austad SN, Troyer DA, Thompson I, Richardson A. A reliable assessment of 8-oxo-2-deoxyguanosine levels in nuclear and mitochondrial DNA using the sodium iodide method to isolate DNA. Nucleic Acid Res. 2001;29(10):2117-2126.

22. Andersen PK, Borgan O, Gill RD, Keiding N. Statistical models based on counting processes. NewYork: SpringVerlag; 1993.

23. Wang C, Li Q, Redden DT, Weindruch R, Allison DB. Statistical methods for testing effects on "maximum lifespan". Mech Ageing Dev. 2004;125(9):629-632.

24. Bronson RT, Lipman RD. Reduction in rate of occurrence of age related lesions in dietary restricted laboratory mice. Growth Dev Aging. 1991;55(3):169-184.

25. Ikeno Y, Hubbard GB, Lee S, Richardson A, Strong R, Fernandez E, Diaz V, Nelson JF. Housing density does not influence the longevity effect of calorie restriction. J Gerontol A Biol Sci Med Sci. 2005;60(12):1510-1517.

26. Ikeno Y, Bronson RT, Hubbard GB, Lee S, Bartke A. The delayed occurrence of fatal neoplastic diseases in Ames dwarf mice: correlation to the extended longevity. J Gerontol A Biol Sci Med Sci. 2003;58(4):291-296.

27. Ikeno Y, Hubbard GB, Lee S, Cortez LA, Lew CM, Rodriguez M, Bartke A. Reduced Incidence and Delayed Occurrence of Fatal Neoplastic Diseases in Growth Hormone Receptor/Binding Protein (GHR/BP) Knockout Mice. J Gerontol A Biol Sci Med Sci. 2009;64A(5):522-529.

28. Abate C, Patel L, Rauscher FJ 3rd, Curran T. Redox regulation of Fos and Jun DNA-binding activity in vitro. Science. 1990;249:1157-1161.

29. Galter D, Mihm S, Droge W. Distinct effects of glutathione disulphide on the nuclear transcripton factor $\mathrm{kB}$ and the activator protein-1. Eur J Biochem. 1994;221:639-648.

30. Toledano MB, Leonard WJ. Modulation of transcription factor NF-KB binding activity by oxidation-reduction in vitro. Proc Natl Acad Sci USA. 1991;88:4328-4332.

31. Matsui M, Oshima M, Oshima H, Takaku K, Maruyama T, Yodoi J. Early embryonic lethality caused by targeted disruption of the mouse thioredoxin gene. Dev Biol. 1996;178(1):179-185.

32. Nonn L, Williams RR, Erickson RP, Powis G. The absence of mitochondrial thioredoxin 2 causes massive apopto- 
sis, exencephaly, and embryonic lethality in homozygous mice. Mol Cell Biol. 2003;23(3):916-922.

33. Yoshihara E, Masaki S, Matsuo Y, Chen Z, Tian H, Yodoi J. Thioredoxin/Txnip: Redoxisome, as a redox switch for the pathogenesis of diseases. Front Immunol. 2013;4:514.

34. Wei SJ, Botero A, Hirota K, Bradbury C M, Markovina S, Laszlo A, Spitz DR, Goswami PC, Yodoi J, Gius D. Thioredoxin nuclear translocation and interaction with redox factor- 1 activates the activator protein- 1 transcription factor in response to ionizing radiation. Cancer Res. 2000;60:6688-6695.

35. Cunningham GM, Flores LC, Roman MG, Cheng C, Dube S, Allen C, Valentine JM, Hubbard GB, Bai Y, Saunders TL, Ikeno Y. Thioredoxin overexpression in both the cytosol and mitochondria accelerates age-related disease and shortens lifespan in male C57BL/6 mice. Geroscience. 2018;40(5-6):453-468.

Cite this article as: Roman M G, Flores L C, Cunningham G M, et al. Thioredoxin overexpression in mitochondria showed minimum effects on aging and age-related diseases in male $\mathrm{C} 57 \mathrm{BL} / 6 \mathrm{mice}[\mathrm{J}]$. Aging Pathobiology and Therapeutics, 2020, 2(1): 20-31. 